\title{
IPM program successful in California greenhouse cut roses
}

\author{
by Christine Casey, Julie Newman, Karen Robb, \\ Steven A. Tjosvold, James D. MacDonald \\ and Michael P. Parrella
}

We developed and tested an integrated pest management (IPM) program for the key pests of cut roses, which was based on fixed precision sampling plans, thresholds, biological control, directed sprays of reducedrisk pesticides, and cultural control. This program represented the largest effort to date to implement an IPM program in U.S. floriculture. The biological control of mites was successful at all locations, and pesticide use was generally lower in the IPM greenhouses. Future work will concentrate on reducing scouting time, improving natural-enemy release methods, and developing IPM techniques for secondary pests and powdery mildew.

$\mathrm{R}$ ose production is currently the largest component of California's $\$ 300$ million cut-flower industry. In 2001, California growers produced $66 \%$ of the U.S. rose crop, with a wholesale value of $\$ 45$ million (USDA 2002). The key pests of cut roses are twospotted spider mites (Tetranychus urticae), western flower thrips (Frankliniella occidentalis) and rose powdery mildew (Sphaerotheca pannosa rosae).

The twospotted spider mite is a foliage feeder that extracts the cell contents from leaves. This feeding causes foliar stippling and can disrupt the plant's photosynthetic and water balance mechanisms (Tomczyk and Kropczynska 1985). The western flower thrips is both a foliage and flower feeder, although it feeds primarily on flowers in the cut-rose system (Robb 1989). Powdery mildew is probably the most widespread and best-known disease of roses. The fungus produces a white, powdery-appearing growth of mycelium and conidia on leaves, which can cause distortion, discoloration and

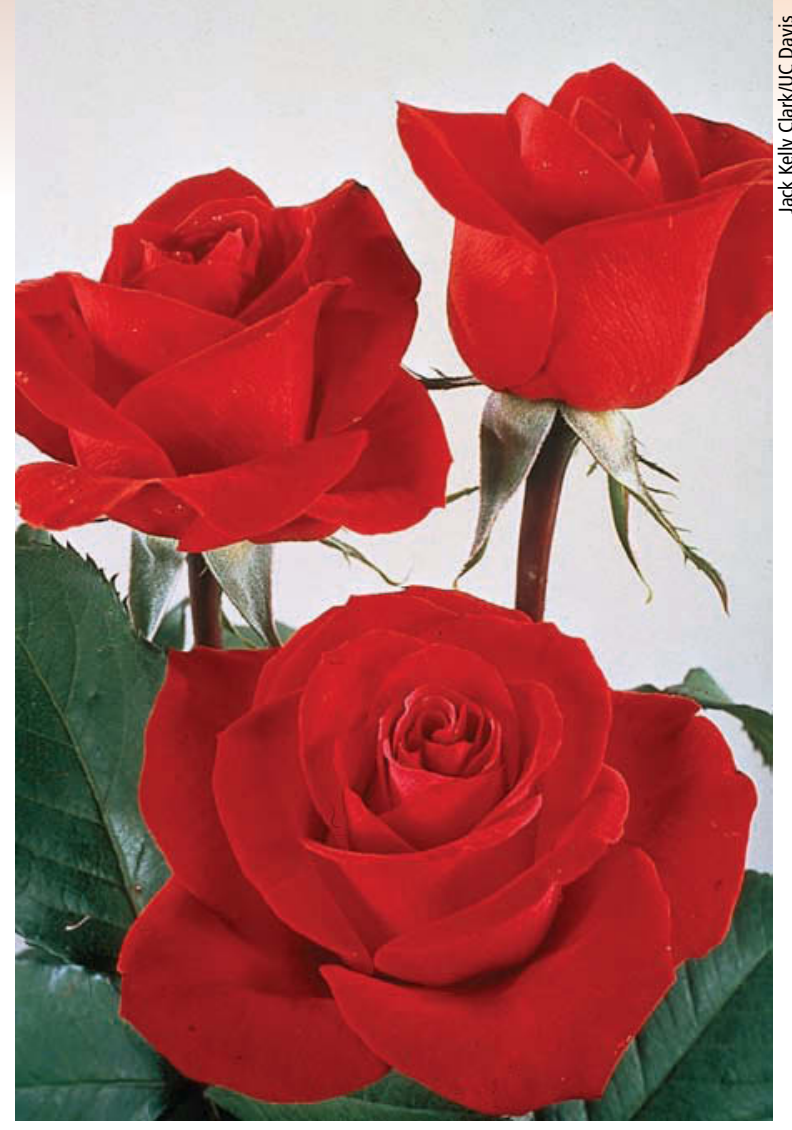

California nurseries produce two-thirds of the cut roses grown in the United States, with a wholesale value of \$45 million. Pest control options have been limited in the past, resulting in the heavy use of pesticides and increasing resistance in important pests such as western flower thrips and twospotted spider mites. premature senescence. Although it causes some disruption of photosynthesis and transpiration control, the key impact of powdery mildew is reduced aesthetic value caused by the white, powdery spots and leaf distortion.

Fresh cut roses are often harvested twice daily, so revised reentry intervals imposed by the U.S. Environmental Protection Agency (EPA) after pesticide application limit the number of pesticides that are useful in this production system (EPA 1995). In addition, the typical number of pesticide sprays applied to roses grown for cut flowers has impeded the implementation of integrated pest management (IPM) procedures, particularly the use of biological controls. The IPM approach to pest management incorporates all cost-effective control tactics appropriate for the crop, including biological, cultural and chemical controls.

Pesticides that target hard-to-kill floriculture pests frequently kill natural enemies as well, which favors continued reliance on conventional pesticides while discouraging the adoption of biological control. Heavy pesticide use against key pests in the greenhouse has resulted in the widespread development of pesticide resistance in western flower thrips (Immaraju et al. 1992; Jensen 2000), mites (Ramdev et al. 1988; Fergusson-Kolmes et al. 1991), whiteflies (Prabhaker et al. 1985), aphids (Kerns and Gaylor 1992) and leafminers (Sanderson et al. 1989). The heavy use of pesticides in cut roses is also a worker safety concern in global (Tenenbaum 2002) and local (Warrick 2000) production. California rose growers reached a crisis point about 8 years ago, when pesticide resistance, costs and limited pesticide availability threatened the growers' ability to effectively manage twospotted spider mites.

At the same time, a new cut-rose production system that favors the success of IPM was gaining widespread acceptance. Roses were traditionally grown in soil with a hedgerow training system, where flowers are cut in a manner that gradually creates a 7-foot 

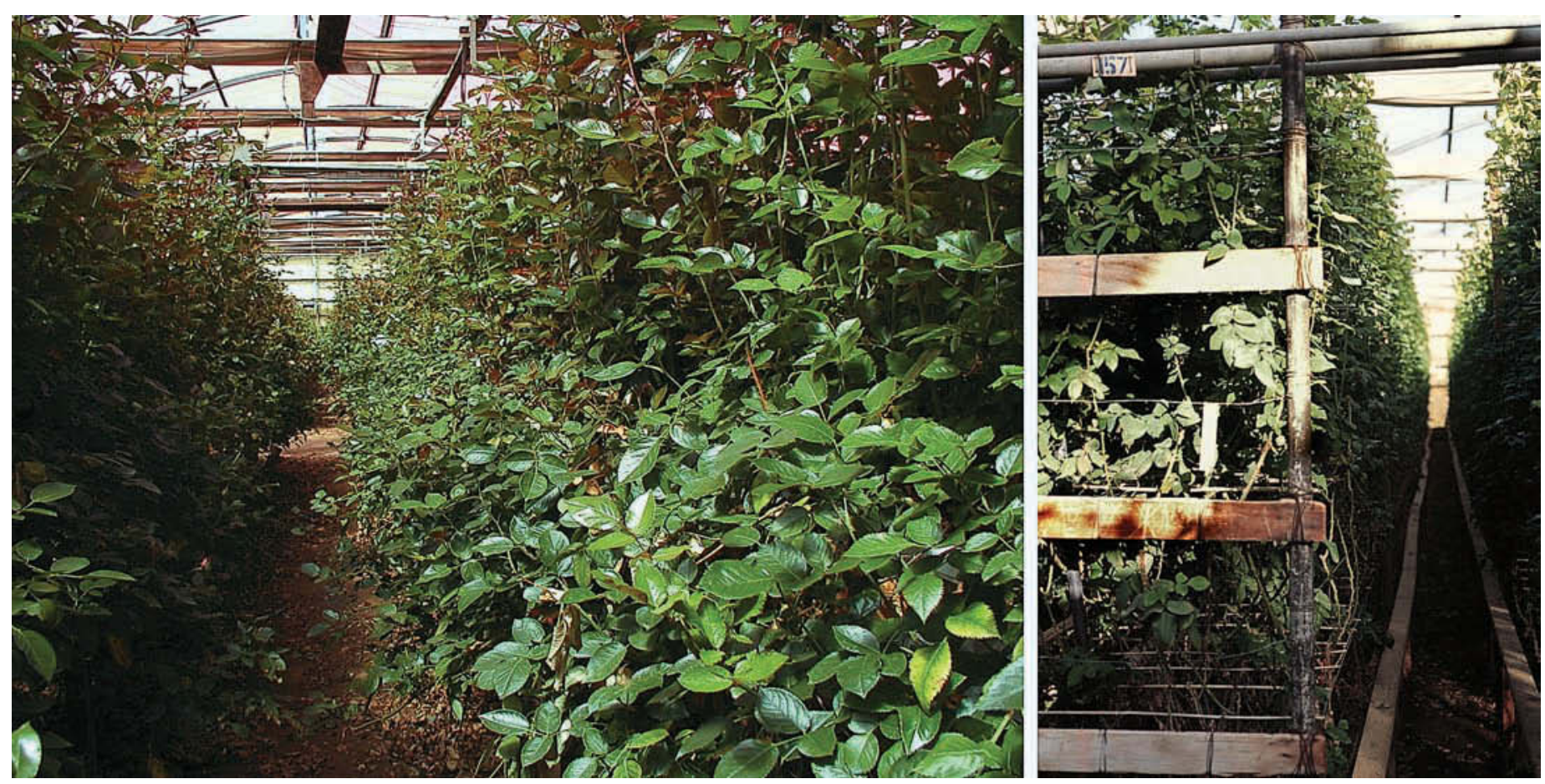

Traditionally, greenhouse cut roses were grown in hedges, right. In the late 1990s, a new bent-shoot system, left, was developed that cultivates plants in raised containers with modified hydroponics. The new bentshoot system helped lay the groundwork of an integrated pest management program for rose growers.

(2.13-meter) or taller hedge. The hedges are pruned back annually to about a 3 -foot height and the process is begun again. With the new bent-shoot method, plants are grown in raised containers in a modified hydroponics system. Most of the shoots are bent downward at the crown to intercept more light, creating a perennial lower canopy that exists for the 5 to 8 years of crop production. The upper canopy contains only stems that produce flowers, which take 45 to 52 days to develop. The bent-shoot method creates a spatial separation between the harvested flowers and perennial foliage that does not exist in standard roses. Pesticides to control western flower thrips and powdery mildew that are more compatible with mite predators have also recently become available. These developments, coupled with the difficulty that rose growers were facing in controlling spider mites, made us confident that we could develop a successful IPM program that rose growers would adopt.

This project was initiated in 2000 with major funding from the Pest Management Alliance Program of the California Department of Pesticide Regulation and was later supplemented with additional funding. The goal of the Alliance project was to foster a team approach to the development and implementation of IPM programs in a given commodity and to document a reduction in traditional pesticide use. Our Alliance team included researchers, county-based advisors, growers, chemical and biological-control industry representatives, commodity associations and government officials. Our objective was to develop a cost-effective IPM program for the key pests of cut roses that included sampling, thresholds, biological control and directed sprays of reduced-risk pesticides.

\section{Implementing the IPM program}

Eight growers spanning the major rose-producing areas of California (San Diego, Santa Barbara and Santa Cruz counties) participated in the program. Each grower contributed an IPM and a conventional-practice greenhouse; all greenhouses were between 5,000 and 10,000 square feet (465 to 929 square meters) in size. All pest management decisions in the IPM greenhouses were based on the IPM program that we developed, while the grower made all pest management decisions in the conven- tional greenhouses. Data was collected and compared on a weekly basis by trained scouts using a comprehensive sampling plan that provided information about the density of insects, mites and diseases. The project included growers with several different rose varieties and both the bent-cane and hedgerow training techniques, but we kept these two variables standardized within a location. Implementation began in March 2000 and continued until January 2001.

Fixed precision sampling plans that had been previously developed for twospotted spider mites (Casey 2002) and western flower thrips (Casey and Parrella 2000) were used in our scouting program. This type of sampling plan was developed through intensive surveys of a crop to determine a pest's spatial distribution. The degree of acceptable error (the "precision" of the plan) was decided upon (or "fixed") in advance, and the number of samples needed to obtain that precision was calculated using knowledge of the pest's spatial distribution in the crop. We used a precision of 0.25 , which is acceptable for pest management sampling (Southwood 1978). Generally, as spatial 
distribution becomes more aggregated (clumped), more samples are required to determine pest density with the desired precision. Although they take some effort to develop, these types of sampling plans are often more accurate and efficient than other sampling approaches. This study represents the first use of such plans in a floriculture IPM program. Sampling for all other pests was done during sampling and inspection for twospotted spider mites. Data was collated and summarized by the scouts and then discussed by members of the Alliance team. The scouts then met with the growers to discuss control strategies. Based on thresholds developed for each of the pests, no action was taken; cultural controls were used; biological control agents were released; or a pesticide application was made. Each greenhouse was a replicate, and ANOVA was used to determine whether there were differences between the conventional and IPM treatments.

\section{Twospotted spider mites}

The first leaf above the bend on 38 randomly selected plants was sampled per 10,000 square feet (929 square meters) of greenhouse area to estimate mite density at the desired precision. Plants were classified as infested if the scout found more than five mobile mites (eggs were not counted) on the sampled leaf, or not infested if there were five or fewer. These samples were also used to determine co-occurrence of twospotted spider mites with the predatory mite Phytoseiulus persimilis, and they were inspected for secondary pests and diseases. In addition to the fixed samples, the scouts took directed samples as they walked down each row and noticed damage by insects, mites or pathogens. These plants were flagged for potential spot treatments.

In the IPM greenhouses, mite treatments were initiated according to the percentage of infested plants (table 1). Chemical controls included azadirachtin (Azatin), bifenazate (Floramite) and insecticidal soap (M-Pede), all of
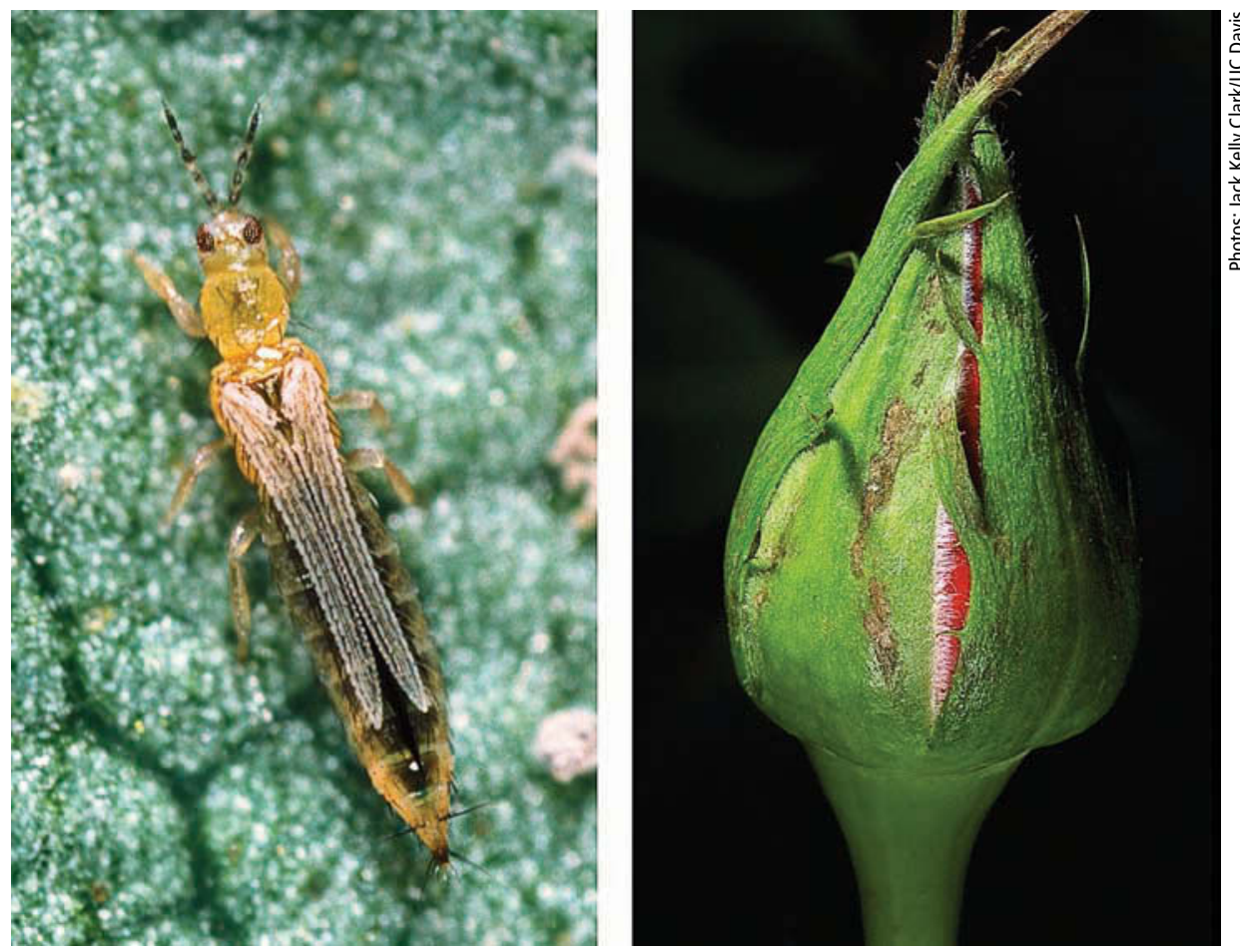

Left, the adult western flower thrips feeds primarily on rose flowers, leaving scabby, brown scars, right, that can indicate feeding in unopened buds. The IPM program developed weekly threshold limits for treating thrips, and tested targeted lower-volume sprays to just the upper canopy of flowers.

which provide some level of compatibility with $P$. persimilis. Releases of predatory mites were based on the cooccurrence of twospotted spider mites and predators on the sampled leaf. Cooccurrence is the percentage of plants with twospotted spider mites on which P. persimilis also occurs. This idea has been discussed in the literature as a theoretical basis for natural enemy releases, but has never been tested in practice (Nachman 1981; Ryoo 1996; Greco et al. 1999). We chose to include this method in our program because our natural enemy supplier recommended it to growers. Additional predatory mites were released when co-occurrence was less than $10 \%$. All predator releases were made to leaves just below those on which twospotted spider mites were present. Predators were kept refrigerated and were released as soon as possible after arrival at the greenhouse, as per the supplier's instructions.

\section{Targeting western flower thrips}

A fixed precision sampling plan for western flower thrips was also developed (Casey and Parrella 2000).
This sampling plan used yellow sticky traps and a general threshold of 25 to 50 thrips per trap per week (Parrella et al. 2003). Three 4-by-6-inch (10by-15-centimeter) yellow sticky traps (Seabright Laboratories) with both sides exposed were placed per 10,000 square feet (929 square meters). The traps were placed at flower level and were evenly distributed in the greenhouse (for example, at the ends and center of the middle row). The lower threshold of 25 thrips per trap per week was used in more-susceptible varieties (generally white or yellow

\begin{tabular}{l}
$\begin{array}{l}\text { TABLE 1. Control actions for twospotted spider } \\
\text { mite based on percentage of infested plants }\end{array}$ \\
\hline \begin{tabular}{ll} 
Mite density & Action \\
\% samples \\
$\begin{array}{ll}\text { infested } & -10\end{array}$ \\
$>10-25^{*}$ & $\begin{array}{l}\text { Do nothing } \\
\text { Biological control (Phytoseiulus } \\
\text { persimilis), with release rate } \\
\text { based on proportion of } \\
\text { co-occurrence of mites and } \\
\text { predators }\end{array}$ \\
& $\begin{array}{l}\text { Chemical controls } \\
>25\end{array}$ \\
\hline $25 \%$ infested $=$ & 4.5 T. urticae/leaf.
\end{tabular}
\end{tabular}




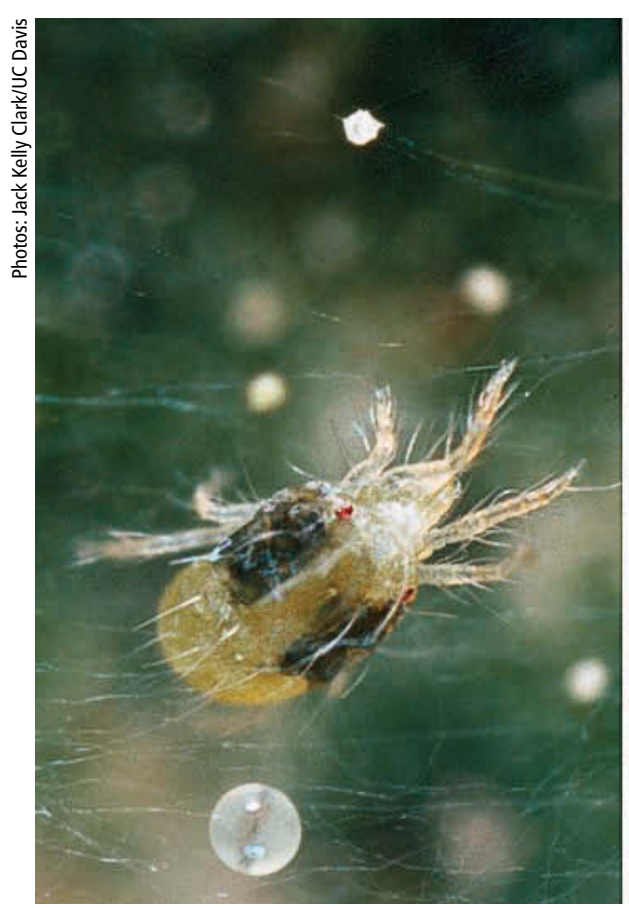

The twospotted spider mite feeds on foliage, disrupting photosynthesis and water usage.

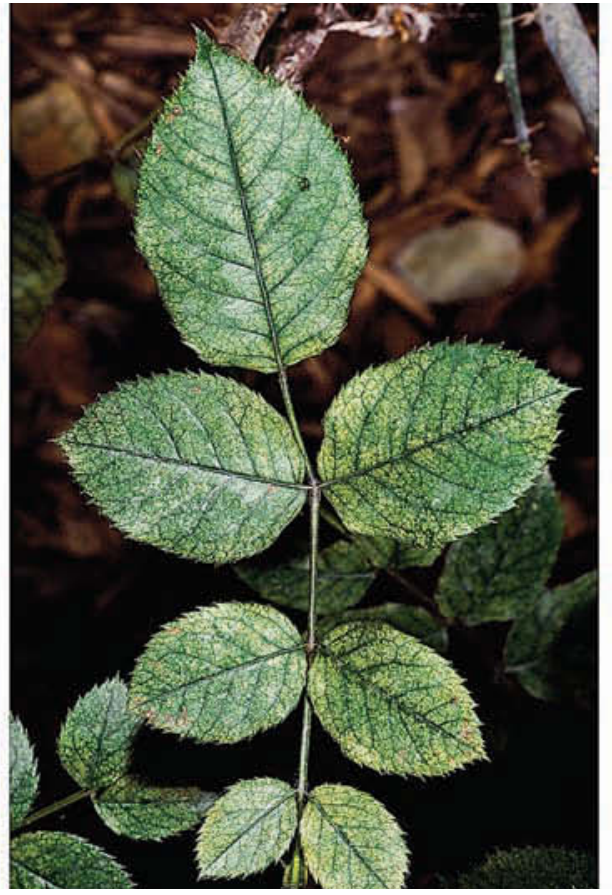

An infestation of twospotted spider mites causes stippled, bleached rose foliage.

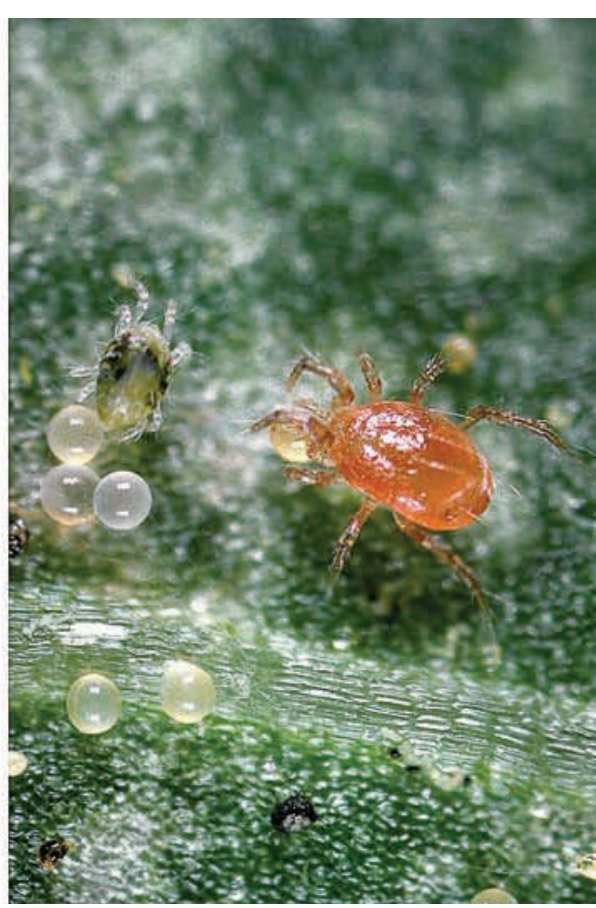

Phytoseiulus persimilis eats twospotted spider mite eggs, acting as a biological control. flowers) and in areas of heavy thrips pressure. The higher threshold of 50 thrips per trap per week was used in less-susceptible varieties (generally red flowers).

There is currently no cost-effective biological control agent for western flower thrips in cut roses, so control of this pest in the IPM greenhouses included both cultural and chemical methods. Although the female thrips lays eggs in the flower or in foliage directly below the flower, the development time for eggs and larvae is longer than the 5 to 6 days between sepal split (when eggs are first laid) and flower harvest (Robb 1989). Routine flower harvest removes immature thrips from the greenhouse and subsequently there is little thrips reproduction in the rose greenhouse unless open flowers (those that are too mature for harvest) are left on the rose plant. Teerling (2000) has measured significantly higher thrips populations in Canadian rose greenhouses when these flowers are not removed.

Cultural control was the removal of open flowers, and chemical control was applications of spinosad (Conserve) or azadirachtin (Azatin) directed to the flowers when the thrips-per-trap-per- week threshold was reached. Research on the distribution of thrips in the rose range has revealed that most thrips are found near the developing flower (Parrella et al. 2003). Based on these findings, we then conducted a trial to determine whether sprays directed toward the flowers would provide control equivalent to full-volume wet sprays.

Such a study is critical to the implementation of IPM in the rose range, because a typical full-volume spray in roses may reach hundreds of gallons of water per acre. Such high volume thoroughly wets the foliage, but creates problems with runoff and affects biological control agents regardless of where they are on the plant. In separate rose greenhouses, we initiated a replicated study where rose beds were divided into 20-foot sections and applications of registered pesticides were made using full-volume wet sprays at 275 gallons per acre (2,555 liters per hectare) versus the same material applied just to the upper canopy (the flowers) at 70 gallons per acre (662.5 liters per hectare). Registered materials - acephate (Orthene), methiocarb (Mesurol) and spinosad (Conserve) - at label-recommended rates were used in the study. There were four replicated, 20-foot (6-meter) rows for each material per volume combination, and applications were made for 4 weeks.

At the end of this time, 10 flowers were removed from each section and examined for the presence of thrips.

\section{Predatory mites were successfully used in all of the IPM greenhouses and almost eliminated the need for miticides.}

Analysis of the mean number of thrips per flower $(t$-test, $P>0.05)$ revealed no difference in the performance of any material, despite the reduction in spray volume (fig. 1). In all subsequent control efforts against thrips in our IPM program, lower-volume directed applications were made. This reduced the amount of runoff and active ingredient used and helped conserve $P$. persimilis that had been released into the lower canopy.

\section{Powdery mildew control}

Our effort to introduce IPM principles in the management of powdery mildew 

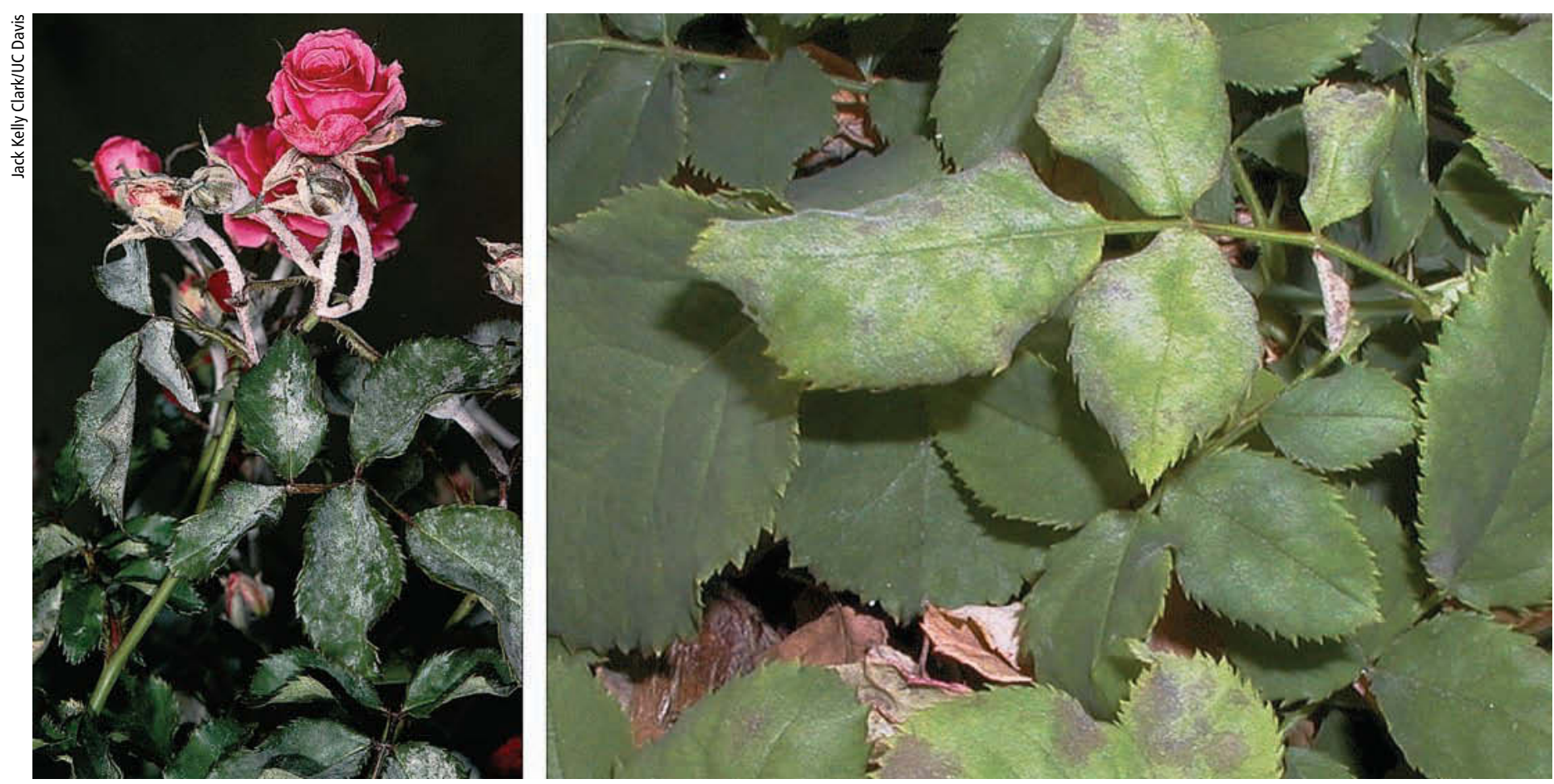

Powdery mildew is a fungus that grows on rose leaves, but usually not flowers or petals. It is generally treated with fungicides to improve the plant's appearance. A better model is needed to predict when and if they should be sprayed.

centered on an attempt to use a predictive model for powdery mildew of grapevines (Gubler et al. 1999). The UC Davis powdery mildew risk-assessment model for grapevines is based on the effect of temperature on the reproductive rate of the pathogen following initial plant infection. As temperatures are recorded in vineyards, risk points are accumulated if temperatures are favorable (between $70^{\circ} \mathrm{F}$ and $85^{\circ} \mathrm{F}$ for 6 hours or longer) or subtracted if temperatures are not favorable. When risk points (on

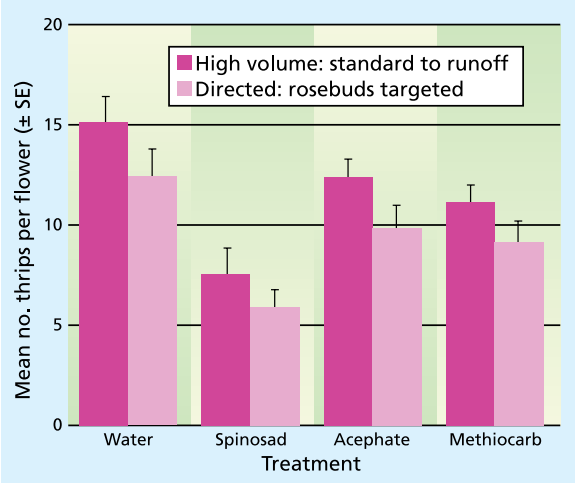

Fig. 1. Thrips control using selected pesticides and different volumes of water. No significant differences were detected when different volumes of water were used, regardless of the insecticide ( $t$-test, $P>0.05$ ). a scale of 0 to 100) reach a predetermined threshold, fungicide application is recommended. This model has been effective in determining if and when fungicide treatments need to be applied to grapevines, and has resulted in effective disease management with significantly reduced fungicide usage in California.

In commercial rose greenhouses, growers spray regularly weekly during mildew season in Central California (April to October) and all year long in Southern California. It is not unusual for half of all yearly pesticide sprays in a rose crop to be for mildew control, presenting a strong argument for matching applications to actual risks. Although the powdery mildew fungus attacking roses is a different species, its response to environmental conditions (Horst 1989) is similar to that of the species attacking grapevines. For this reason, we sought to determine whether the grapevine mildew model (GMM) could be easily adapted to greenhousegrown roses.

The greenhouses used in this effort were instrumented so that temperature, relative humidity and leaf wetness were measured at 30-minute intervals throughout the day and night. Temperature data was fed into the GMM to add or subtract risk points. In order to correlate actual disease development with the GMM risk points, a trained scout evaluated plants in the greenhouses weekly. This was accomplished by walking through the greenhouses in a predetermined pattern, stopping at regular intervals and evaluating one plant at each stop-point to assess disease incidence and severity. Disease incidence was determined by the presence or absence of mildew lesions on the leaves of harvestable stems. Disease severity was determined by counting the actual number of lesions on leaves attached to the harvestable stems. This data was used to calculate an overall disease rating for the crop that could be compared to risk predictions based on the GMM.

Along with the disease incidence and severity data, we recorded the timing of all chemical fungicide and insecticide applications made by the growers in the IPM houses so that we could evaluate these effects on disease ratings. As a resistance management practice, growers typically varied the fungicide materials used throughout 


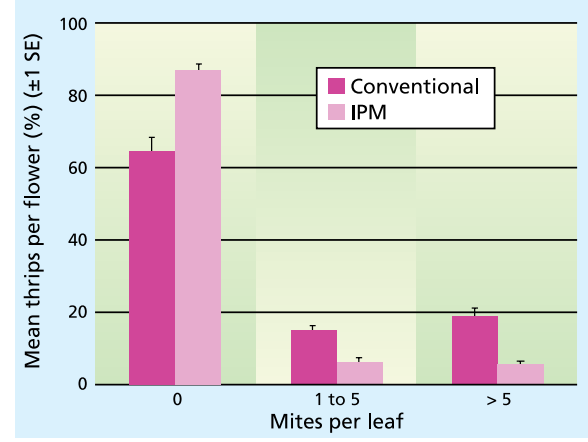

Fig. 2. Twospotted spider mite densities under conventional and IPM programs across all nurseries. There were significantly more plants with no mites $(P<0.0001 ; F=33.84)$ and significantly fewer plants with mites at the other levels measured ( 1 to $5 /$ leaf, $P<0.0001$, $\mathrm{F}=22.88$; $>$ 5/leaf, $P<0.0001, \mathrm{~F}=23.33$ ).

the season. A few fungicides were common across all locations, but growers did differ in some of the materials applied. For example, if powdery mildew became severe in a greenhouse, growers at all locations would typically apply piperalin (Pipron) because of its eradicative properties. Other materials used at the various locations included myclobutanil (Systhane), chlorothalonil (Daconil), benzeneacetic acid (Compass), azoxystrobin (Heritage), insecticidal soap (M-Pede) and potassium bicarbonate (Kaligreen).

\section{Monitoring for secondary pests}

Plants in both the IPM and conventional greenhouses were inspected for whiteflies, aphids, mealybugs, Botrytis, downy mildew and rust as part of the inspections for twospotted spider mites. The same traps that were used to monitor western flower thrips were also used to monitor whiteflies and winged aphids. We emphasized the use of materials that were compatible with the P. persimilis predator for control of these pests when necessary.

\section{Was the IPM program successful?}

Twospotted spider mites. Predatory mites were successfully used in all of the IPM greenhouses and almost eliminated the need for miticide applications in those houses. A comparison of twospotted spider mite levels under IPM and conventional control across all nurseries revealed that there were significantly more plants with no mites (0 mites/leaf) and significantly fewer

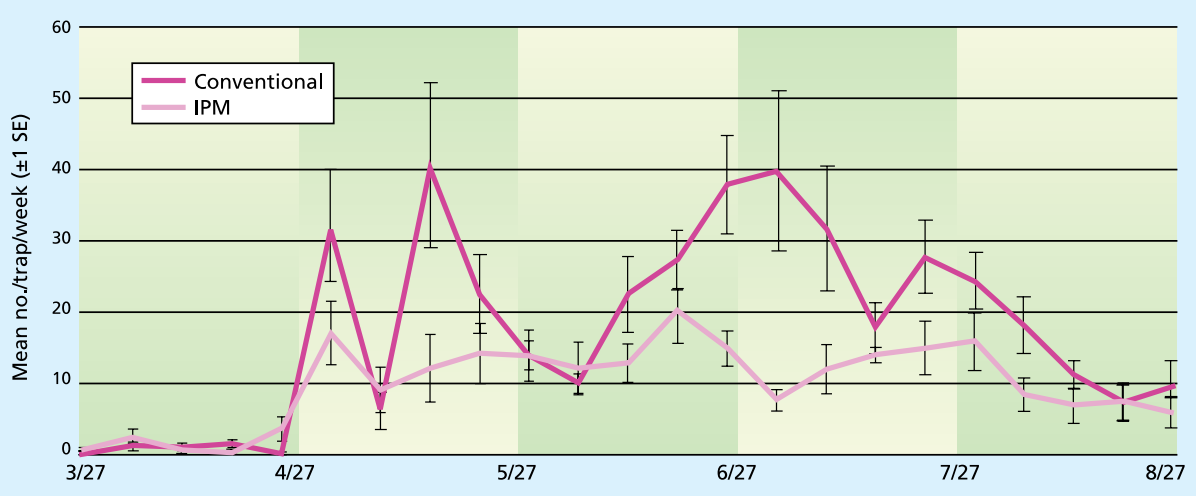

Fig. 3. Western flower thrips populations in conventional versus IPM greenhouses by date. The largest differences in thrips levels between the conventional and IPM treatments were observed from mid-June to mid-August 2000, the period of peak thrips pressure. There was a significant difference between thrips populations under the two control techniques $(P<0.0001, \mathrm{~F}=34.13)$

plants with mites at the two levels measured in the IPM greenhouses (1 to 5 mites/leaf and $>5$ mites/leaf) (fig. 2). Similar results were observed at the individual nurseries.

The cost of IPM during the first 8 weeks was higher than the cost of conventional control (table 2). Higher release rates were needed during this startup period for several reasons, including increased predator mortality as growers learned proper release techniques and the desire of some growers to begin biological control when twospotted spider mite densities were greater than the 25\% infested threshold. After several releases had been made and predators became established, the release rate dropped and costs for the two control programs were comparable.

Western flower thrips. The monitoring program and the use of reducedrisk pesticides to control western flower thrips worked very effectively in the IPM greenhouses. This was a critical component of the entire program, because thrips are considered the key pest of roses. The need to control thrips with pesticides often limits the use of biological control in floriculture crops. Significantly fewer western flower thrips were caught in the IPM houses than in the conventional houses across all nurseries. The largest differences in thrips levels between the two treatments occurred during the summer months, when western flower thrips pressure is generally highest (fig. 3). There were also greater fluctuations in the overall densities of western flower thrips in the conventional houses, as well as more variation between individual conventional houses during the time of peak thrips pressure, compared to the IPM greenhouses. We attribute both of these observations to the regular removal of open flowers in the lower canopy that occurred under IPM but not in the conventional houses.

Powdery mildew. Our attempt to use the grape mildew model without modification to predict powdery mildew infection in greenhouse-grown roses was not satisfactory. The GMM is based on a sustained (6 hours or longer) temperature threshold of $70^{\circ} \mathrm{F}$ to $85^{\circ} \mathrm{F}$, which is a little higher than optimum for mycelial growth of the rose mildew pathogen (Horst 1989). For this reason, we attempted to improve the performance of the model by running it with a temperature range of either $65^{\circ} \mathrm{F}$ to $85^{\circ} \mathrm{F}$ or $65^{\circ} \mathrm{F}$ to $80^{\circ} \mathrm{F}$.

Generally, we found the model to be of limited value in Southern California;

\begin{tabular}{|c|c|c|}
\hline \multicolumn{3}{|c|}{$\begin{array}{l}\text { TABLE 2. Miticide costs under conventional } \\
\text { control, IPM startup (first } 4 \text { to } 8 \text { weeks) } \\
\text { and IPM maintenance }\end{array}$} \\
\hline Treatment & $\begin{array}{c}\text { Cost/ft }{ }^{2} / \\
\text { application }\end{array}$ & $\begin{array}{c}\text { Amount } \\
\text { used per } \\
\text { application* }\end{array}$ \\
\hline Conventional & $\begin{array}{l}\$ 0.006 \\
\text { to } \$ 0.01\end{array}$ & $\begin{array}{c}100 \text { to } \\
150 \text { gallons }\end{array}$ \\
\hline IPM startup & $\begin{array}{l}\$ 0.02 \text { to } \\
\$ 0.03\end{array}$ & 1 to 50 vials \\
\hline $\begin{array}{l}\text { IPM } \\
\text { maintenance }\end{array}$ & $\begin{array}{l}\$ 0.005 \text { to } \\
\$ 0.008\end{array}$ & 2 to 5 vials \\
\hline
\end{tabular}




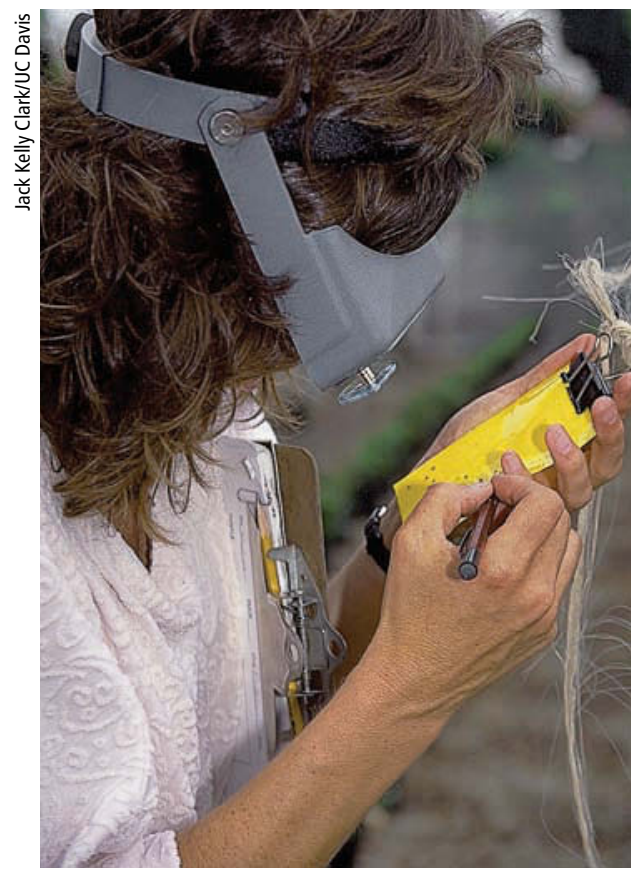

A scout uses a hand-magnifier to count insects on a yellow sticky trap, in order to help growers make better pestmanagement decisions.

it showed a high level of disease risk most times of the year, and disease was a chronic problem. There was no clear start to a mildew season, and there was little success in identifying environmental changes associated with changes in disease pressure. On the other hand, Central California greenhouses did appear to have a seasonal component to disease, with powdery mildew on greenhouse roses starting in early spring (coincident with mildew on roses outside the greenhouse) and tapering off by early fall.

However, even under these conditions, the model was not successful in identifying triggering events. For example, there was a poor relationship between the powdery mildew index (PMI) in a greenhouse near Monterey when the model was run with a temperature range of $65^{\circ} \mathrm{F}$ to $85^{\circ} \mathrm{F}$ (fig. $4 \mathrm{~A}$ ). This relationship was improved somewhat by running the model for the same data using a temperature range of $65^{\circ} \mathrm{F}$ to $80^{\circ} \mathrm{F}$ (fig. $4 \mathrm{~B}$ ). However, there were many times in the spring and early summer when the PMI indicated high disease risk but no disease was evident on the crop (fig. 4C). We have no explanation for these persistent failures. Perhaps there was no inoculum in the greenhouse; perhaps we

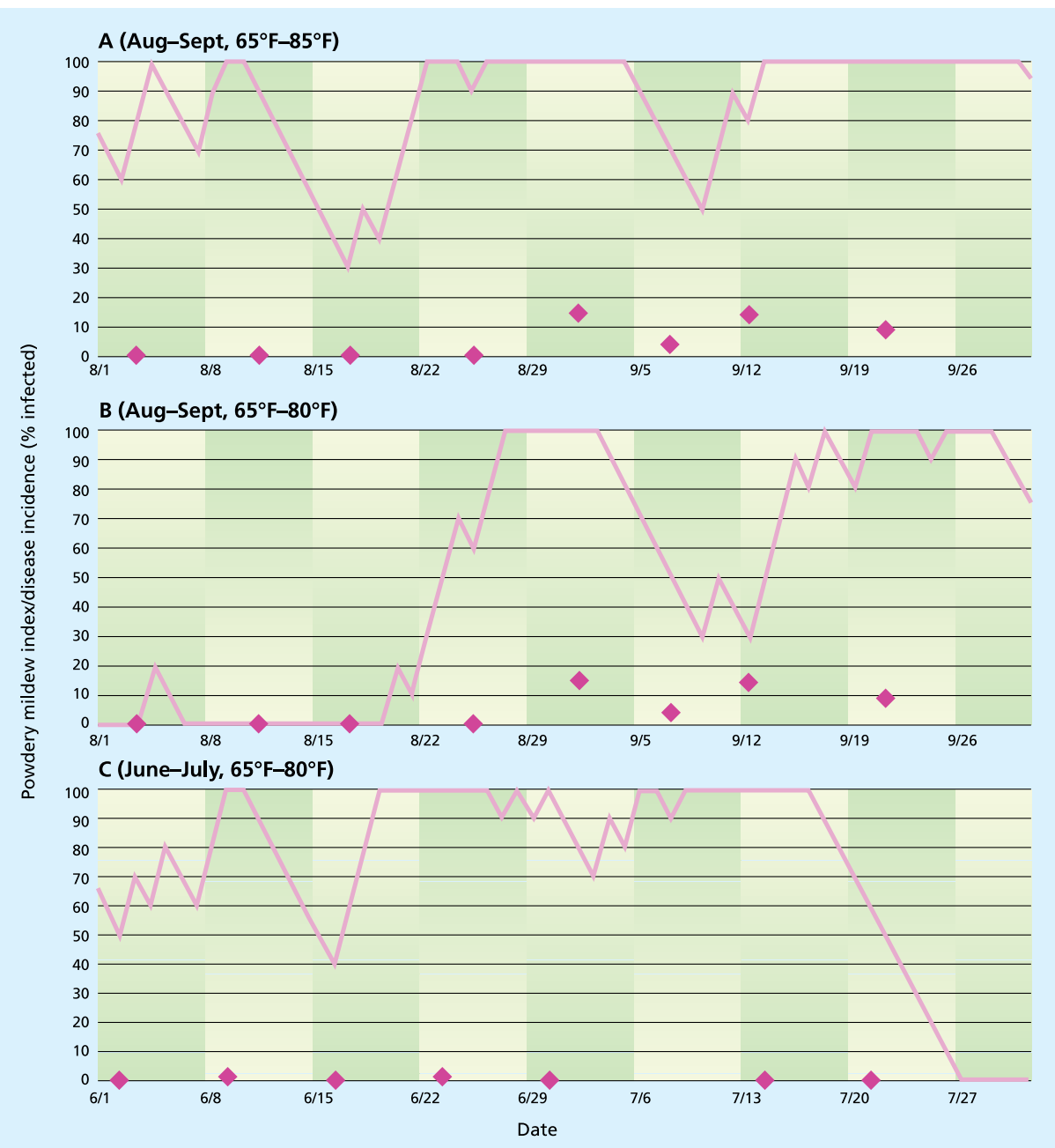

Fig. 4. Comparison of the powdery mildew index (PMI) computed by the grapevine mildew model (solid lines) relative to observations of actual disease incidence (diamonds) in a Monterey rose greenhouse for (A and B) August to September and (C) June to July 2000.

were not fully aware of all fungicide treatments; or perhaps greenhouse humidity is interacting in a way that confounds the model.

Clearly a model that could predict the most opportune times for applying fungicide treatments to control powdery mildew on roses would be beneficial. We were encouraged by the fact that the model never indicated low risk when there was in fact significant disease (data not shown), and that we sometimes saw a rise in mildew incidence after a rise in the index with an appropriate latent period lag (figs. 4A, 4B). However, our research showed that the UC Davis powdery mildew risk assessment model for grapevines is not easily adapted to the challenge of powdery mildew on greenhouse roses. Additional research is needed to develop a more suitable modeling platform before it will be possible to effectively advise growers regarding risk periods.

Secondary pests. Effective IPM implementation was hindered at two sites by the citrus mealybug (Planococcus citri). This pest is generally not a problem for rose growers until IPM is implemented, when the cessation of broad-spectrum pesticide applications can allow this pest to develop. It is generally a problem only at sites where roses are or were grown adjacent to other flower crops such as Stephanotis, an important citrus mealybug host plant. Unfortunately, natural enemies of the citrus mealybug are not regularly available at the commercial level, and the most effective mealybug pesticides are detrimental to spider mite predators. We are working with the natural enemy suppliers to try to change this situation, and we continue to evaluate reduced-risk pesticides for efficacy against the citrus mealybug. 


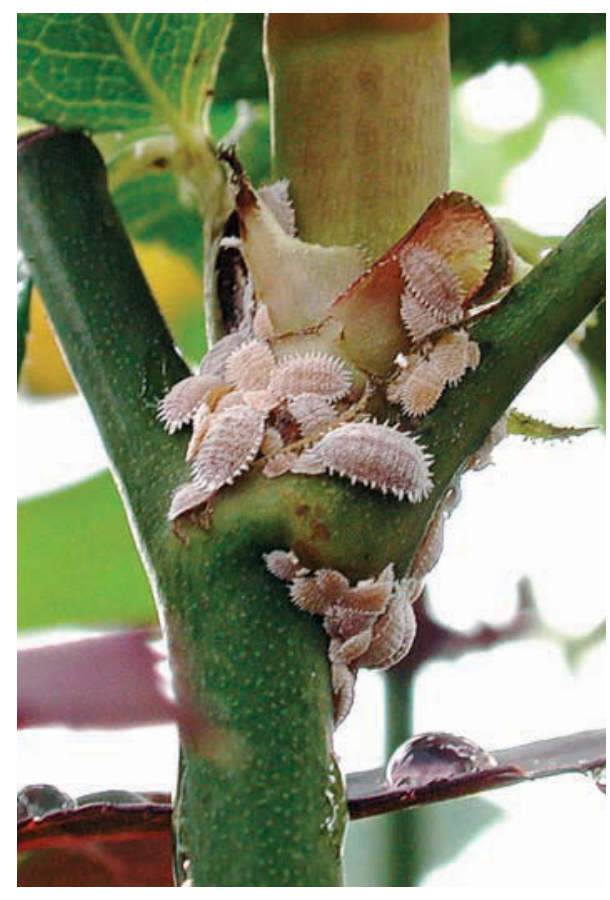

\section{Past success, future work}

Overall, we believe that the rose IPM program was successful. For example, most of the growers participating in the study wanted to abandon their conventional treatments in favor of using a biological control, predatory mites, to control twospotted spider mites; we allowed them to do so after we felt that enough data had been collected for a good comparison of the IPM and $\varangle$ Citrus mealybug became a pest at two study sites after broad-spectrum pesticide spraying ceased. This is generally a problem only where roses are grown adjacent to other flowers that serve as mealybug hosts.

conventional treatments. Future work should concentrate on reducing the sampling effort while still collecting sufficient information to support good pest management decisions. In addition, more work is needed on refining the predictive powdery mildew model as well as on developing effective IPM techniques for secondary pests.

This program represents the first and largest effort to demonstrate and implement an IPM strategy on floriculture crops in the United States. Drawing on the partnerships that are central to the Pest Management Alliance concept, we have shown that high-quality roses can be produced with substantially fewer pesticides and with the incorporation of biological control into mainstream floriculture. Effective partnering with the biological control industry has also been a hallmark of this program. This has led to the widespread use of predatory mites in commercial rose production in California, representing the largest use of biological control by the floriculture industry in the United States.
C. Casey is Assistant Professor of Entomology, North Carolina State University, Raleigh, N.C.; J. Newman is Environmental Horticulture Farm Advisor, UC Cooperative Extension (UCCE), Ventura County; K. Robb is Farm Advisor/County Director, UCCE Mariposa County; S.A. Tjosvold is Environmental Horticulture Farm Advisor, UCCE Santa Cruz County; J.D. MacDonald is Professor, Department of Plant Pathology, UC Davis; and M.P. Parrella is Professor of Entomology, UC Davis. In addition to funding from the California Department of Pesticide Regulation, we received support from the American Floral Endowment, the California Association of Nurserymen, the California Cut Flower Commission, the International Cut Flower Grower's Association, the UC Davis Center for Pest Management Research and Extension, the UC Integrated Pest Management Program, and the USDA-ARS Nursery and Floriculture Research Initiative. We would also like to acknowledge the generous weekly contribution of Phytoseiulus persimilis by Syngenta Bioline. Most importantly, we thank the cooperating growers: Aspen Nurseries, Dramm and Echter, Kitayama Brothers, Kocher Flowers, Myriad Flowers, Roseflor, Sunshine Flowers and Westerlay Roses. The technical support of Linda Bolkan, Heidi Petersen and Carla Thomas is greatly appreciated.

\section{References}

Casey C. 2002. Distribution, thresholds, and biological control of the twospotted spider mite (Tetranychus urticae Koch) on greenhouse grown roses. Ph.D. dissertation, UC Davis. 133 p.

Casey C, Parrella M. 2000. Development and implementation of an integrated pest management program for greenhouse cut roses. Presented at IOBC-NRS Thrips Research Workshop, June 20-3. Niagara, Ontario.

[EPA] US Environmental Protection Agency. 1995. Exception to worker protection standard early entry restrictions. Fed Reg 40 CFR Part 170 (May 3):21955 www.epa.gov/fedrgstr/EPA-PEST/1995/May/Day-03/ pr-238.html.

Fergusson-Kolmes L, Scott J, Dennehy T. 1991. Dicofol resistance in Tetranychus urticae (Acari: Tetranychidae): Cross-resistance and pharmacokinetics. J Econ Entomol 84:41-8.

Greco N, Liljesthröm G, Sánchez N. 1999. Spatial distribution and coincidence of Neoseiulus californicus and Tetranychus urticae (Acari: Phytoseiidae, Tetranychidae) on strawberry. Exp Appl Acarol 23:567-80.

Gubler WD, Rademacher MR, Vasquez SJ, Thomas CS. 1999. Control of powdery mildew using the UC Davis powdery mildew risk index. APSnet Feature. Jan 6-31. www.apsnet.org/online/feature/pmildew.

Horst RK. 1989. Compendium of Rose Diseases. St. Paul, MN: APS Pr. 50 p.
Immaraju J, Paine T, Bethke J, et al. 1992. Western flower thrips (Thysanoptera: Thripidae) resistance to insecticides in coastal California greenhouses. J Econ Entomol 85:9-14.

Jensen S. 2000. Insecticide resistance in the western flower thrips, Frankliniella occidentalis. IPM Rev 5:131-46

Kerns D, Gaylor M. 1992. Insecticide resistance in field populations of the cotton aphid (Homoptera: Aphididae). J Econ Entomol 85:1-8

Nachman G. 1981. Temporal and spatial dynamics of an acarine predator-prey system. J Animal Ecol 50:435-51.

Parrella MP, O'Donnell C, Murphy BC, Casey C. 2003. Thrips. In: Roberts A, Debener T, Guidin S (eds.) Encyclopedia of Rose Science. Amsterdam: Elsevier. p 437-43.

Prabhaker N, Coudriet D, Meyerdirk D. 1985. Insecticide resistance in the sweetpotato whitefly, Bemisia tabaci (Homoptera: Aleyrodidae). J Econ Entomol 78:748-52.

Ramdev Y, Lindquist R, Hall F. 1988. Evaluation of resistance to Pentac and bifenthrin in nine spider mite populations from Ohio greenhouses. Ohio Florists Assoc Bull 704:6-8.

Robb K. 1989. Analysis of Frankliniella occidentalis (Pergande) as a pest of floricultural crops in California greenhouses. Ph.D. dissertation, UC Riverside. 135 p.
Ryoo M. 1996. Influence of the spatial distribution pattern of prey among patches and spatial coincidence on the functional and numerical response of Phytoseiulus persimilis (Acarina, Phytoseiidae). J Appl Entomol 120:187-92.

Sanderson JP, Parrella MP, Trumble JT. 1989 Monitoring insecticide resistance in Liriomyza trifolii (Diptera: Agromzidae) with yellow sticky cards. J Econ Entomol 82(4):1011-8.

Southwood TRE. 1978. Ecological Methods (2nd ed.). London: Chapman Hall. 592 p.

Teerling C. 2000. Management of thrips through production practices and biological control. Presented at IOBC-NRS Thrips Research Workshop, June 20-3. Niagara, Ontario.

Tenenbaum D. 2002. Would a rose not smell as sweet? Problems stem from the cut flower industry. Env Health Persp 110(5):A240-7.

Tomczyk A, Kropczynska D. 1985. Effects on the host plant. In: Helle W, Sabelis MW (eds.). Spider Mites: Their Biology, Natural Enemies and Control. Amsterdam: Elsevier. $405 \mathrm{p}$.

[USDA] US Department of Agriculture. 2002 USDA Floriculture Crops 2001 Summary. USDA-NASS Sp Cr 6-1(02).

Warrick J. 2000. Fresh cut flowers: Fragrant, beautiful - and often doused with pesticides. Nat Wildlife (June/July):12-3. 